\title{
Neonatal abstinence syndrome in a newborn delivered by an opioid- -dependent mother using methadone substitution therapy during pregnancy
}

\begin{abstract}
Introduction. Psychoactive substances as opioids used by women during pregnancy can have a negative impact on the health of a newborn child.

Case report. Based on a case report of a newborn delivered by an opioid-dependent mother, this article describes the therapeutic decision-making that occurred in caring for this patient. This included outlining the form of substitution therapy selected and the use of Finnegan's scoring system to assess the degree of abstinence syndrome in the newborn.

Conclusion. There is a need to monitor drug-dependent women and their children from the early stages of pregnancy through to birth to ensure positive health outcomes for both the mother and the newborn.

Palliat Med Pract 2020; 14, 2: 124-126
\end{abstract}

Key words: opioid, dependence, methadone maintenance treatment, neonatal abstinence syndrome

\section{Introduction}

The use of psychoactive substances including alcohol, nicotine as well as prescribed medicines such as opioids may have a negative impact on the progression of pregnancy and the health of the newborn. Women sometimes also take several substances at the same time, increasing the risk of adverse effects upon on the foetus. Neonatal abstinence syndrome (NAS) is an opioid withdrawal syndrome caused by maternal opioid dependence and is diagnosed in the newborn infant following birth. Signs of NAS often manifest within $48 \mathrm{~h}$ of delivery and mainly concern the nervous system and gastrointestinal tract [1-3]. In 20095.63 per 1000 delivering women in the US were identified as dependent or using opioids during delivery, and the subsequent prevalence of NAS occurred at a rate of 3.39 per 1000 hospital births per year [2]. The purpose of this case study was to describe and analyze the health of a neonate born with NAS. A specific objective was to report on the therapeutic interventions performed for the child, both pharmacological and non-pharmacological.

\section{Case description}

Following a full-term pregnancy (39 weeks' gestation), a male baby was delivered via a normal, vaginal birth. This child was the second pregnancy and second childbirth for the mother. The pregnancy

\footnotetext{
Address for correspondence:

Iga Pawłowska

Department of Pharmacology, Medical University of Gdańsk, Poland

e-mail: iga.pawlowska@gumed.edu.pl
}

Palliative Medicine in Practice 2020; 14, 2, 124-126

Copyright (c) Via Medica, ISSN 2545-0425

DOI: $10.5603 / \mathrm{PMPI} .2020 .0012$ 
was complicated by the mother's dependency on opioids (heroin). Under appropriate medical supervision, she had been receiving oral methadone (syrup, $1 \mathrm{mg} / 1 \mathrm{ml}$ ) in decreasing doses for 2 years before the pregnancy. The initial dose was $100 \mathrm{mg} /$ day (before pregnancy) and was tapered down to $35 \mathrm{mg} /$ day in the last two months of pregnancy. The pregnancy was further complicated by the mother acquiring a vaginal Streptococcus agalactiae infection and also being identified as an HCV carrier. The vaginal infection was attributed to inadequate antibiotic prophylaxis in the perinatal period.

The child was born in a stable condition (10 points on Apgar score), with a birth weight of $3420 \mathrm{~g}$. The patient's anthropometric measurements were found to be following the standards for postpartum age. From the beginning of the second hour of life, the child's general condition deteriorated. There was an observed increase in respiratory disturbances, and he appeared to develop peripheral cyanosis. On further examination, the infant was found to be suffering respiratory acidosis, hypoxemia, and lung interstitial markings were identified on chest $X$-rays. The worsening condition of the child required passive oxygenation in the incubator, which was then increased to respiratory Continuous Positive Airway Pressure (CPAP) support (Infant Flow Bi Phasic) due to respiratory failure. Antibiotic therapy and parenteral nutrition were introduced. The child remained in serious condition. The child developed limb tremors and became agitated, which required sedation. After 24 hours, the respiratory disturbances improved, CPAP was discontinued, and enteral nutrition was introduced. In the next few hours, clinical features of NAS were observed and included: neurological disturbances, agitation, unsettled crying, tremors, difficulty in bottle-feeding (frantic sucking) and numerous loose and watery stools. The neonate scored 16 points on the Finnegan neonatal abstinence scoring scale. Due to insufficient lactation at the beginning, the neonate was fed using modified milk and later using breast milk. Monitoring highlighted that bradycardia occurred during sleep. A physiotherapist's consultation indicated the following signs: slow and impaired reflexes, foot clonus, tremor of upper and lower limbs and frantic sucking.

Both pharmacological and non-pharmacological (calm environment, rocking) treatments were applied. Pharmacotherapy included oral morphine syrup (the starting dose was $0.02 \mathrm{mg} / \mathrm{kg}$ every $4 \mathrm{~h}$, and due to poor symptom relief, the dose was increased to $0.2 \mathrm{mg} / \mathrm{kg}$ ). From the 15th day of treatment, a slow improvement was observed, allowing a gradual reduction of the dose of morphine. A Finnegan scale score of below 4 points was achieved at a dose of $0.04 \mathrm{mg} / \mathrm{kg}$.
The parameters were as follows: HR 140-168/min (bradycardia disappeared) and saturation $\mathrm{O}_{2} 92-98 \%$. The child was discharged from hospital 22 days after his birth in a stable condition. The mother was advised to continue his care in the Neonatal Pathology Clinic.

\section{Discussion}

Substance abuse may have serious consequences for an addicted woman, as well as the potential to impact significantly on foetal development and postnatal adaptation. When considering the consequences of opioids use in pregnancy, there have been reported incidences of NAS, respiratory distress as well as perinatal deaths in cases of sudden opioid withdrawal by pregnant women. Maternal opioid substitution therapy is recognized as an effective preventative measure against adverse effects on the foetus from repeated opioid withdrawals and periods of intoxication [4]. The most commonly used pharmacotherapy for treating opioid-dependency in pregnant women is maintenance therapy using methadone and is regarded as a safe pharmacotherapeutic option for these patients $[1,5]$. However, replacement therapy may also be a direct cause of NAS [6].

Methadone maintenance treatment (MMT) may be a targeted form of treatment or a first step towards achieving full abstinence. This form of substitution therapy can be started before as well as during the pregnancy. Methadone is a potent $\mu$-opioid receptor agonist, it blocks NMDA receptors and the reuptake of monoaminergic neurotransmitters. In comparison to morphine or heroin, it has better oral bioavailability and a much longer half-life [4]. As such, withdrawal signs and symptoms appear milder and are more prolonged. According to some studies, it is highlighted that the benefits of using MMT in pregnant women include better patient compliance with the physician during perinatal care, less incidence of somatic diseases and healthier infants born of these women, in comparison to those whose mothers were treated using other methods $[4,7]$. Furthermore, MMT is reported to have less of an impact on foetal development and decreases the risk of obstetric complications, including perinatal deaths. Methadone is known to cross the placenta and enters human milk, however, because of the benefits, breastfeeding is not contraindicated [8].

The reported dosing ranges of methadone in pregnancy vary considerably. Some literature highlights that high doses are preferred to reduce the potential risk of illicit drug use, whereas alternatively, lower doses are credited with decreasing the potential risk of NAS in the infant $[9,10]$. Generally, when used in pregnant women, the lowest doses of methadone are 
selected to prevent the occurrence of opioid withdrawal symptoms [7]. Overall, dosing of methadone is dependent on individual patient responses to this opioid, however, in most cases, it ranges $60-120 \mathrm{mg} / 24 \mathrm{~h}$ (oral formulation, e.g. syrup). It is taken once a day due to its long half-life (24-36 h) [4, 7].

One of the most significant consequences of opiate addiction during pregnancy, including the use of methadone, is the development of NAS in the child [6]. NAS is described as a collection of signs and symptoms that occur in a newborn who at birth is no longer exposed to the psychoactive substances taken by the mother during pregnancy, leading to the development of signs of withdrawal. These may include irritability, tremors, feeding difficulties due to problems sucking and breathing troubles. As a tool for assessing the severity of clinical symptoms, the Finnegan scoring system can be applied to evaluate the neonates neurological, digestive and autonomic systems. These scores can be used to help diagnose and plan treatment. Therapy aims to stabilize clinical symptoms and to restore the child's normal activity. Initially, non-pharmacological therapy is preferred, however in newborns who score highly, pharmacological treatment is initiated. Primary non-pharmacological methods including a calm environment, sleep and frequent feeding in small portions are recommended. In cases where diarrhoea and vomiting are present, rehydration, parenteral nutrition and the supplementation of extra calories are required.

Pharmacological treatment is used to relieve the discomfort and withdrawal symptoms of children with severe clinical symptoms (50-70\%). The medicines used to alleviate these symptoms are usually in the same drug class as the substances that the child is "withdrawing" from. The first-line therapy of choice is morphine or methadone [6]. When withdrawal symptoms are controlled, the dose and time of administration are gradually reduced to help wean the child from the drug.

\section{Conclusion}

There is a need to monitor drug-dependent women and their children from the early stages of pregnancy through to birth to ensure positive health outcomes for both the mother and the newborn [7]. Women who use substitution therapy programs are more likely to benefit from perinatal care and potential risks are identified more quickly resulting in a significant decrease in pregnancy and birth-related complications and birth defects among children of drug-dependent mothers [11].

\section{Conflict of interests}

Authors declare no conflict of interest.

\section{Funding}

This study has no funding.

No identifiable information about the patient is included in the manuscript.

\section{References}

1. Kocherlakota P. Neonatal Abstinence Syndrome. PEDIATRICS. 2014; 134(2): e547-e561, doi: 10.1542/peds.20133524.

2. Patrick SW, Schumacher RE, Benneyworth BD, et al. Neonatal abstinence syndrome and associated health care expenditures: United States, 2000-2009. JAMA. 2012; 307(18): 1934-1940, doi: 10.1001/jama.2012.3951, indexed in Pubmed: 22546608.

3. World Health Organization. Operational guidelines for the management of opioid dependence in the South-East Asia Region, 2018. http://apps.who.int/iris/bitstream/10665/205591/1/B3229. pdf?ua=1 (11 March 2020).

4. Lingford-Hughes AR, Welch S, Peters L, et al. British Association for Psychopharmacology, Expert Reviewers Group. BAP updated guidelines: evidence-based guidelines for the pharmacological management of substance abuse, harmful use, addiction and comorbidity: recommendations from BAP. J Psychopharmacol. 2012; 26(7): 899-952, doi: 10.1177/0269881112444324, indexed in Pubmed: 22628390.

5. Rostami-Hodjegan A, Wolff K, Hay AW, et al. Population pharmacokinetics of methadone in opiate users: characterization of time-dependent changes. $\mathrm{Br} \mathrm{J}$ Clin Pharmacol. 1999; 48(1): 43-52, doi: 10.1046/j. 1365-2125.1999.00974.x, indexed in Pubmed: 10383559.

6. Logan BA, Brown MS, Hayes MJ. Neonatal abstinence syndrome: treatment and pediatric outcomes. Clin Obstet Gynecol. 2013; 56(1): 186-192, doi: 10.1097/GRF.0b013e31827feea4, indexed in Pubmed: 23314720.

7. ACOG Committee on Health Care for Underserved Women, American Society of Addiction Medicine. ACOG Committee Opinion No. 524: Opioid abuse, dependence, and addiction in pregnancy. Obstet Gynecol. 2012; 119(5): 1070-1076, doi: 10.1097/AOG.0b013e318256496e, indexed in Pubmed: 22525931.

8. Müller MJ, Lange M, Paul T, et al. [Breast feeding during methadon- and buprenorphin therapy]. Klin Padiatr. 2011; 223(7): 408-413, doi: 10.1055/s-0031-1283193, indexed in Pubmed: 21969026.

9. Drozdick J, Berghella V, Hill M, et al. Methadone trough levels in pregnancy. Am J Obstet Gynecol. 2002; 187(5): 1184-1188, doi: $10.1067 / \mathrm{mob} .2002 .127132$, indexed in Pubmed: 12439500.

10. Wolff K, Boys A, Rostami-Hodjegan A, et al. Changes to methadone clearance during pregnancy. Eur J Clin Pharmacol. 2005; 61 (10): 763-768, doi: 10.1007/s00228-005-0035-5, indexed in Pubmed: 16261362.

11. Women and Newborn Drug and Alcohol Service. Neonatal Abstinence Syndrome (NAS) Western Australia: King Edward Memorial Hospital. https://www.wnhs.health. wa.gov.au/ /media/Files/Hospitals/WNHS/Our\%20Services/WANDAS/wnhs 0197.pdf (11 March 2020). 


\section{Zespół abstynencyjny u noworodka}

urodzonego przez matkę uzależnioną

od opioidów stosującą podczas ciąży terapię substytucyjną metadonem

Artykuł jest tłumaczeniem pracy: Napieralska M., Pawłowska I., Krzyżaniak N., Neonatal abstinence syndrome in a newborn delivered by an opioid-dependent mother using methadone substitution therapy during pregnancy. Palliat. Med. Pract. 2020 tom 14, nr 1: 124-126.

Należy cytować wersję pierwotną.

Piśmiennictwo znajduje się na stronie 126.

\section{Streszczenie}

Wstęp. Substancje psychoaktywne, takie jak opioidy stosowane przez kobiety w ciąży, mogą negatywnie wpłynąć na zdrowie noworodka.

Opis przypadku. Opierając się na opisie przypadku noworodka urodzonego przez matkę uzależnioną od opioidów, przedstawiono proces podejmowania decyzji dotyczących postępowania terapeutycznego w opiece nad pacjentką. Nakreślono formę wybranej terapii substytucyjnej oraz wykorzystanie systemu punktacji Finnegan do oceny stopnia zaawansowania zespołu abstynencyjnego u noworodka.

Wniosek. Konieczne jest monitorowanie kobiet uzależnionych od narkotyków i ich dzieci, począwszy od wczesnego etapu ciąży aż do porodu, w celu zapewnienia korzystnych efektów zdrowotnych zarówno dla matki, jak i dla noworodka.

Palliat Med Pract 2020; 14, 2: 127-129

Słowa kluczowe: opioid, uzależnienie, metadonowa terapia podtrzymująca, zespół abstynencyjny u noworodków

\section{Wstęp}

Używanie substancji psychoaktywnych, w tym alkoholu, nikotyny, a także leków wydawanych z przepisu lekarza, takich jak opioidy, może mieć negatywny wpływ na przebieg ciąży i zdrowie noworodka. Ponadto niejednokrotnie kobiety zażywają kilka substancji jednocześnie, co zwiększa ryzyko wystąpienia działań niepożądanych szkodliwych dla płodu. Zespół abstynencyjny u noworodków (NAS, neonatal abstinence syndrome) jest zespołem odstawienia opioidów spowodowanym uzależnieniem od opioidów matki, diagnozowanym u noworodka po urodzeniu. Objawy przedmiotowe NAS często pojawiają się w przeciągu 48 godzin od porodu i dotyczą głównie układu nerwowego i przewodu pokarmowego [1-3]. W 2009 roku w Stanach Zjednoczonych u 5,63 na 1000 rodzących kobiet stwierdzono uzależnienie od opioidów lub ich

Adres do korespondencji:

Iga Pawłowska

Zakład Farmakologii, Gdański Uniwersytet Medyczny, Gdańsk, Polska

e-mail: iga.pawlowska@gumed.edu.pl 
stosowanie, a następnie współczynnik występowania NAS wyniósł 3,39 na 1000 urodzeń w szpitalu rocznie [2].

Celem niniejszego studium przypadku było opisanie i analiza zdrowia noworodka urodzonego z NAS. Celem szczegółowym było przedstawienie informacji na temat przeprowadzonych $u$ dziecka interwencji terapeutycznych, zarówno farmakologicznych, jak i niefarmakologicznych.

\section{Opis przypadku}

Ciąża donoszona (39. tydzień ciąży), noworodek płci męskiej, poród pochwowy o prawidłowym przebiegu. Dla matki dziecka była to druga ciąża i drugi poród. Ciążę komplikowało uzależnienie matki od opioidów (heroiny). Pod stosownym nadzorem lekarskim przez 2 lata przed ciążą przyjmowała doustnie metadon (syrop, $1 \mathrm{mg} / 1 \mathrm{ml}$ ) w malejących dawkach. Dawka początkowa wynosiła $100 \mathrm{mg} /$ dobę (przed ciążą) i w ostatnich dwóch miesiącach ciąży została zmniejszona do 35 mg/dobę. Ciążę dodatkowo komplikowało wystąpienie u matki zakażenia pochwy wywołanego przez Streptococcus agalactiae, a także ustalenie, że jest ona nosicielem HCV. Zakażenie pochwy przypisywano nieodpowiedniej profilaktyce antybiotykowej w okresie okołoporodowym.

Dziecko urodziło się w stanie stabilnym (10 punktów w skali Apgar), z urodzeniową masą ciała $3420 \mathrm{~g}$. Stwierdzono, że pomiary antropometryczne pacjenta są zgodne z normami dla wieku poporodowego. Począwszy od drugiej godziny życia, stan ogólny dziecka uległ pogorszeniu. Zaobserwowano wzrost częstości występowania zaburzeń oddychania i pojawienie się sinicy obwodowej. Dalsze badania wykazały, że niemowlę cierpi na kwasicę oddechową, hipoksemię, a zdjęcia RTG klatki piersiowej uwidoczniły smugowate cienie charakterystyczne dla chorób śródmiąższowych płuc. Pogarszający się stan dziecka wymagał zastosowania natleniania biernego w inkubatorze, które następnie z powodu niewydolności oddechowej zostało zwiększone do wspomagania ciągłym dodatnim ciśnieniem oddechowym (CPAP, Continuous Positive Airway Pressure) przy zastosowaniu techniki Infant Flow Bi Phasic. Wdrożono antybiotykoterapię i żywienie pozajelitowe. Stan dziecka nadal był określany jako poważny. U dziecka wystąpiły drżenia kończyn, a następnie pojawiło się pobudzenie wymagające sedacji. Po upływie 24 godzin nastąpiła poprawa wydolności oddechowej, zaprzestano stosowania CPAP i wprowadzono żywienie dojelitowe. W następnych godzinach zaobserwowano objawy kliniczne NAS, obejmujące: zaburzenia neurologiczne, pobudzenie, niedający się ukoić płacz, drżenia, trudności w karmieniu butelką (nadmierne ssanie) oraz liczne luźne i wodniste stolce. Noworodek uzyskał 16 punktów w skali Finnegan. Z powodu niewystarczającej laktacji na początku noworodek był karmiony mlekiem modyfikowanym, a później mlekiem kobiecym. Monitoring wykazał występowanie bradykardii podczas snu. Konsultacja fizjoterapeuty potwierdziła obecność następujących objawów przedmiotowych: spowolnienie i upośledzenie odruchów, stopotrząs, drżenie kończyn górnych i dolnych oraz nadmierne ssanie.

Zastosowano zarówno leczenie farmakologiczne, jak i niefarmakologiczne (spokojne otoczenie, kołysanie). Farmakoterapia obejmowała podanie morfiny doustnie w postaci syropu (dawka początkowa wynosiła 0,02 mg/kg co 4 godz., ale ze względu na niewystarczający stopień ustępowania objawów dawkę zwiększono do 0,2 mg/kg). Począwszy od 15. dnia leczenia zaobserwowano powolną poprawę, pozwalającą na stopniowe zmniejszanie dawki morfiny. W skali Finnegan uzyskano wynik poniżej 4 punktów przy dawce $0,04 \mathrm{mg} / \mathrm{kg}$. Parametry były następujące: HR 140-168/min (bradykardia ustąpiła) i nasycenie $\mathrm{O}_{2}$ 92-98\%. Dziecko wypisano ze szpitala 22 dni po urodzeniu w stanie stabilnym. Matce zalecono kontynuację leczenia w Klinice Patologii Noworodka.

\section{Dyskusja}

Nadużywanie substancji może pociągać za sobą poważne konsekwencje dla uzależnionej kobiety, jak również może mieć znaczący wpływ na rozwój płodu i adaptację poporodową. Analizując następstwa stosowania opioidów w okresie ciąży, odnotowano występowanie NAS, niewydolności oddechowej, a także zgonów okołoporodowych w przypadku nagłego odstawienia opioidów przez kobiety ciężarne. Substytucyjna terapia opioidowa matki jest uważana za skuteczne zapobieganie występowaniu działań niepożądanych szkodliwych dla płodu po wielokrotnym odstawianiu opioidów i okresach ostrego odurzenia [4]. Najczęściej stosowaną farmakoterapią w leczeniu uzależnienia od opioidów u kobiet w ciąży jest metadonowa terapia podtrzymująca i jest ona postrzegana jako bezpieczna opcja farmakoterapeutyczna dla tych pacjentek [1, 5]. Niemniej jednak, terapia zastępcza może stanowić również bezpośrednią przyczynę NAS [6].

Metadonowa terapia podtrzymująca (MMT, methadone maintenance treatment) może być ukierunkowaną formą leczenia lub pierwszym krokiem w kierunku osiągnięcia pełnej abstynencji. Tego rodzaju terapię substytucyjną można rozpocząć zarówno przed, jak i w trakcie ciąży. Metadon jest silnym agonistą receptorów $\mu$-opioidowych, blokuje receptory NMDA i wychwyt zwrotny monoaminergicznych 
neuroprzekaźników. W porównaniu z morfiną czy heroiną charakteryzuje się lepszą biodostępnością po podaniu doustnym i znacznie dłuższym okresem półtrwania [4]. Tym samym objawy przedmiotowe i podmiotowe odstawienia wydają się łagodniejsze i przedłużają się. W niektórych badaniach wykazano, że do korzyści płynących ze stosowania MMT u kobiet w ciąży należy zaliczyć lepsze przestrzeganie zaleceń lekarza podczas opieki okołoporodowej, mniejszą częstość występowania chorób somatycznych oraz lepszy stan zdrowia noworodków urodzonych przez te kobiety, w porównaniu z tymi, których matki były leczone $z$ zastosowaniem innych metod [4, 7]. Ponadto stwierdzono, że MMT w mniejszym stopniu wpływa na rozwój płodu i zmniejsza ryzyko powikłań położniczych, w tym śmiertelności okołoporodowej. Wiadomym jest, że metadon przenika przez łożysko i przedostaje się do mleka kobiecego, jednak biorąc pod uwagę korzyści płynące z karmienia piersią, taki sposób karmienia nie jest przeciwwskazany [8].

Zgłaszane dawki metadonu przyjmowane podczas ciąży różnią się znacząco. Niektóre publikacje wskazują, że duże dawki są korzystniejsze w celu zmniejszenia potencjalnego ryzyka nielegalnego zażywania narkotyków, podczas gdy mniejszym dawkom przypisuje się zmniejszenie potencjalnego ryzyka wystąpienia NAS u niemowlęcia [9, 10]. Z reguły, w przypadku stosowania u kobiet $w$ ciąży, dobiera się najmniejsze dawki metadonu, aby zapobiec wystąpieniu objawów podmiotowych odstawienia opioidów [7]. Ogólnie rzecz biorąc, dawkowanie metadonu zależy od indywidualnej reakcji pacjentki na ten opioid, jednak $w$ większości przypadków wynosi ono 60-120 mg/dobę (preparat doustny, np. syrop). Przyjmuje się go raz dziennie ze względu na jego długi okres półtrwania (24-36 godz.) [4, 7].

Jedną z najistotniejszych konsekwencji uzależnienia od opiatów w czasie ciąży, w tym stosowania metadonu, jest wystąpienie NAS u dziecka [6]. Zespół abstynencyjny u noworodków jest określany jako zespół objawów przedmiotowych i podmiotowych, występujących u noworodka, który po urodzeniu nie jest już narażony na działanie substancji psychoaktywnych przyjmowanych przez matkę w czasie ciąży, co prowadzi do powstania objawów przedmiotowych odstawienia. Objawy te mogą obejmować: drażliwość, drżenie, trudności z karmieniem spowodowane problemami z ssaniem i problemami z oddychaniem. System punktacji Finnegan, jako narzędzie do oceny nasilenia objawów klinicznych, może być wykorzystywany do oceny układu neurologicznego, pokarmowego i autonomicznego noworodków. Punkty te mogą być wykorzystywane do wspomagania diagnozy i planowania leczenia. Celem terapii jest stabilizacja objawów klinicznych i przywrócenie prawidłowej aktywności dziecka. Początkowo preferuje się terapię niefarmakologiczną, jednak u noworodków, które uzyskały wysokie wyniki, wdraża się leczenie farmakologiczne. Wskazane są podstawowe metody niefarmakologiczne, takie jak spokojne otoczenie, sen i częste karmienie niewielkimi porcjami. W przypadku wystąpienia biegunki i wymiotów konieczne jest nawadnianie, żywienie pozajelitowe i dostarczanie dodatkowych kalorii.

Leczenie farmakologiczne stosuje się w celu złagodzenia dyskomfortu i objawów podmiotowych odstawienia u dzieci z poważnymi objawami klinicznymi $(50-70 \%)$. Leki stosowane w celu złagodzenia tych objawów podmiotowych należą zazwyczaj do tej samej klasy leków, co substancje, które dziecko „odstawia". Leczeniem pierwszego rzutu jest zastosowanie morfiny lub metadonu [6]. Kiedy objawy podmiotowe odstawienia zostają opanowane, dawka i czas podawania są stopniowo zmniejszane, aby pomóc dziecku w odzwyczajeniu się od narkotyku.

\section{Wniosek}

Konieczne jest monitorowanie kobiet uzależnionych od narkotyków i ich dzieci, począwszy od wczesnego etapu ciąży aż do porodu, w celu zapewnienia korzystnych efektów zdrowotnych zarówno dla matki, jak i dla noworodka [7]. Kobiety objęte programami terapii substytucyjnej częściej korzystają z opieki okołoporodowej, a potencjalne zagrożenia są szybciej rozpoznawane, co prowadzi do znacznego zmniejszenia powikłań w czasie ciąży i porodu oraz wad okołoporodowych wśród dzieci matek uzależnionych od narkotyków [11].

\section{Konflikt interesów}

Autorzy deklarują brak konfliktu interesów.

\section{Finansowanie}

Badanie nie było finansowane.

Manuskrypt nie zawiera informacji, które mogłyby umożliwić identyfikację pacjenta. 